Crocheted Indonesian Language Learning with the Environment

\title{
Lisna Oktari/19016099
}

lisna18oktari@gmail.com

The environment is an important part in human life because, in his life of man occupies the environment as a place to survive and do various activities. The environment is also a place of development of human life. Lingkunganlah that affect good or bad human behavior. This is due to the influence of the environment on life. However, in the environment we often encounter a variety of problems. When learners experience this, educators can engage students in utilizing the surrounding environment as a medium of learning fun. The base of this learning also can raise the correlation of social learners include value as well as the procedures. It can also help students rethink the relationship of human use of the environment and are aware of and consider the matter in the surrounding environment.

According to Tung and Wihardjo (in Ramadan et al, 2019), the problems that occur in the environment caused by human activities that careless and intensive in the area where he lived, this was done to improve the quality of life respectively. A lot of people do not think of the environment when doing things that can damage the environment. Most of them only think of yourself and not think about any impact that would occur from these actions. The impact of his actions as, littering will result in a contaminated environment and the occurrence of floods. This is because a selfish attitude that exists in human beings.

Environment is a place to interact a lot of people. The environment is the beginning of human life, how the development of the language a person starting from the environment. Good poor man can be judged from the environment. In everyday life situations, attitudes manners will give a positive impact on social relations with the environment (Gani, 2019). In learning, especially languages of indonesia's environment can affect the quality of the human. Naturally children will recognize the 
language as a way of communicating with people around Suardi et al (2019). This means that the communication of the child starting from its environment, the better the child's environment that the better the communication the language gets.

According to Nkwetisma (in Ramadan et al, 2019), environmental education is a business that is done consciously to teach and attract the attention of human beings about how the function of the natural environment and how human beings can manage and protect it. Ramadan et al (2019) said that environmental education is important to improve the attitude and awareness of students towards the environment. Environmental education can make students think critically and contextually. How to think critically and contextually this effect later on Indonesian language learning, so between environmental education and language learning are interrelated.

According to Lai and Buldur (in Ramadan et al, 2019), environmental education can be applied in the learning process directly in the classroom. In Indonesian language learning can connect the material about the environment with the materials taught. Ramadan et al (2018) stated environmental education is able to help the student rethink the relationship or correlation between humans and their environment. The correlation starts from understanding the environment, aware of environmental problems, and consider the environmental issues related to human life.

In addition, the presence-based learning environment, students will be more sensitive to environmental conditions. Thus, teachers utilize the environment to train, familiarize, and motivate learners to think critically and creatively. Zulhafizh et al (2013) stated that attitudes and learning motivation of students contribute to the learning outcomes, that is the language of Indonesia. Not only the students, teachers also need to think creatively utilize the environment to be used as learning media. Therefore, the teacher is a facilitator for the students. This is in line with the statement of Sukma (2012) and Ramadan et al (2019) the teacher serves as a facilitator and manager of the learning in the learning process

Based on the student respondents to the questionnaires that have been created by the author of "Regard Indonesian Language Learning with the Environment" to 15 students of Universitas Negeri Padang, 3 students from Universitas Bunghatta, 8 students from the University of Andalas, 2 students from the Open University, and 7 students from the State University of Jakarta. Of the 
overall student above is only 35 people who participate in filling out the questionnaire, the more dominant women 23 respondents and male 12 respondents with a percentage of $65.7 \%$ female, $34,3 \%$ of men. The results of the data of the percentage of the questionnaire that has been done through the google form can be seen as follows.

The first statement, "the Material environment is closely associated with kehidupn day-to-day" of $44.1 \%$ stated strongly agree, 55,9\% agree, $0 \%$ expressed less agreed, and $0 \%$ disagree. The second statement, "the Material environment in the Indonesian language brings positive value for students" 34,3\% stated strongly agree, 62,9\% agree, 2.8 percent expressed less agreed, and 0\% disagree. The third statement, "Learning about the material environment, directly or indirectly, can develop a mindset of students" $20 \%$ stated strongly agree, $77,1 \%$ agree, a $2.9 \%$ said less agreed, and $0 \%$ disagree. Statement of the fourth, "a Learning-based environment aimed at making students participate in the keep, preserve, and protect about" 34,3\% stated strongly agree, $60 \%$ agree, a $5.7 \%$ stated less agreed, and $0 \%$ disagree. Statement of the fifth, "the Efforts in the preservation of the environment can be incorporated kealam reading texts the language of Indonesia" 31,4\% stated samgat agree, 68,6\% agree, $0 \%$ expressed less agreed, and 0\% disagree. Statement sixth, "the Use of media literacy in Indonesian language learning can increase the awareness of students on the importance of the environment" 37,1\% stated strongly agree, 62,9\% agree, $0 \%$ expressed less agreed, and 0\% disagree. Statement of the seventh, "a Learning-based environment can increase creativity in learners" 31,4\% stated strongly agree, 68,6\% agree, $0 \%$ expressed less agreed, and 0\% disagree. Statement of the eighth, "the Material environment can be used as the theme in to create a masterpiece of literature" of $25.7 \%$ stated strongly agree, $71,4 \%$ agree, $0 \%$ expressed less agreed, and 2.9\% disagree. Statement of the ninth, "the Material environment needs to be one of the indicators in the Indonesian language learning" 31,4\% stated strongly agree, 62,9\% agree, a 5.7\% stated less agreed, and 0\% disagree. Statement of the tenth, "the Utilization of the environment is one of the learning media that is better to be applied in the process of learning the language of Indonesia" 31,4\% stated strongly agree, $62,9 \%$ agree, a $2.85 \%$ stated less agreed, and a $2.85 \%$ disagree. 
Based on the results of the answers of the questionnaire conducted, the authors conclude that regard, Indonesian language learning with the environment is very influential. It is proved that in the questionnaire higher number percentage strongly agree and agree rather than disagree and agree. Environmental education can be put into direct learning Indonesian language. Students can diintruksikan to make the text being studied with the theme of the environment. According to the author crocheted Indonesian language learning environment can facilitate teachers and students in teaching and understanding the material bahasa Indonesia motivating, creative, fun, and rewarding. The author hopes that menerapan environmental education that exist in Indonesian language learning can make the environment better for the future.

\section{BIBLIOGRAPHY}

Buldur A and Ömeroglu E. (2018). An examination of the relationship between pre-school children and their teacher' attitute and awareness towards the environment Journal of Education and Learning, 7(2). 221-9.

Gani, E. (2019). The unity of the Indonesian Language in Speech Acts Banned and Criticized on the Seven Etni. 15(2), pages 195-295.

Lai C S.(2018). A study of fifth graders' environmental learning outcomes in Taipei International Journal of Research in Education and Science, 4(1). 252-61.

Nkwetisma C M. (2011). EFL/ESL and environmental education: towards an eco-applied linguistic awareness in Cameroon World Journal of Education, 1(1). 110-18.

Ramadan, S., Sukma, E., \& Indriyani, V. (2019). Environmental education and disaster mitigation through language learning. IOP Conference Series: Earth and Environmental Science, 314. 
Ramadan, S., Yasnur Beautiful, and Vivi Indriyani . (2018). Learning Module Design Writing Argumentative Text Based Problem-Based Learning. Advances in Social Science, Education and Humanities Research, Vol 263. 194-200.

Sukma, Elfia. (2012). Learning Literature Integrative BerbasisKompetensi. International Conference on Languages and Arts, Pages 432-436.

Sukma E. et.al. (2019). Problems in Oral Language Teaching in Primary School. Advances in Social Science. Education and Humanities Research, Vol 301.

Tung C Y, Huang C C and Kawata C. (2002) The effects of different environmental education programs on the environmental behaviors of 8th grade students and related factors the Journal of Environmental Health, 64(7). 24-9. 